\title{
Technology and femininity in Marcel L'Herbier's L'Inhumaine Katherine Shingler
}

\begin{abstract}
:
This article examines the intersection of technology and femininity in Marcel L'Herbier's 1924 silent film L'Inhumaine, focusing on the film's articulation of a figure of machinewoman who may be read as alternately inhuman and posthuman. The article draws on previous scholarship by Maureen Shanahan and others who have read the film through the lens of queer theory, but contends that any queer potentiality is effectively shut down at the end of the film. Offering a new reading of the mysterious machine that is used to reanimate and transform the heroine, I argue that the vision of a posthuman, technologically-mediated woman that emerges at the end of the film is far from emancipatory, and that despite its questioning of normative femininity, L'Inhumaine ultimately advances a conservative gender politics that chimes with a broad social and cultural retour à l'ordre in 1920s France.
\end{abstract}

Keywords: machine-woman, posthuman, queer theory, silent film, technology of orgasm

Although something of a flop at the time of its release in 1924, Marcel L'Herbier's silent film L'Inhumaine $^{1}$ has more recently been feted by scholars as a modernist masterpiece, for its innovative cinematography and editing, its lavish Art Deco sets, its celebration of jazz, and its exploration of futuristic technologies. ${ }^{2}$ Indeed, it is possible to read the film as an instantiation of Futurism in the broad sense, a continuation of the pre-war 'Futurist Moment' which celebrated the expressive possibilities of new technologies of travel and communication. ${ }^{3}$ However, L'Inhumaine is more than a naive hymn to technological progress, and the aim of the present article is to unpick the highly complex ways in which representations of technology and femininity intersect in the film, considering in particular L'Herbier's articulation of a figure of technologically-mediated woman who is, at different points, alternately inhuman and posthuman.

Rosi Braidotti has recently read L'Inhumaine alongside Fritz Lang's Metropolis (1927), pointing out the connection between the central female characters in these films, both of whom are transformed, remade, or reanimated by technology. For Braidotti, both L'Herbier's Claire (the 'inhuman woman' of the film's title) and Lang's robot Maria are alluring yet threatening figures, bespeaking fears about the powers of a rampant, uncontrolled technological apparatus equated, within the allegorical schema of both films, with the female body. She says of L'Inhumaine: 
The film deals with the super-human capacity of the female of our species to manipulate and control the course of human history and evolution. A highly seductive alliance is struck between the female body and the accelerating powers of technology. The ambivalence of fear and desire towards technology is re-cast in the mode of an ancestral patriarchal suspicion towards powerful women and women in positions of power. The progressive promise as well as the destructive potential of the female body-machine is held in close and calculated balance.

Situating both Lang's and L'Herbier's films within a broader twentieth-century tendency both to gender technology as female and to eroticize it, Braidotti summarizes the significance of their machine-women as follows:

Both machine-vamp and praying mantis, both virgin-mother and pregnant suicide bomber, L'Herbier's character Claire in L'Inhumaine and Lang's Maria express the highly sexualized and deeply gendered relationship of the twentieth century to its industrial technology and machinery. ${ }^{4}$

Braidotti is certainly not the first scholar to highlight the critical significance of gender in these films or in other modernist responses to the material textures and psycho-social effects of what Walter Benjamin called 'the age of mechanical reproduction'. ${ }^{5}$ One might indeed be tempted to think of Lang and L'Herbier's technologized women as instances of a broader modernist 'techno-primitive' imaginary, to borrow Hal Foster's term: a range of responses to technology that tend to situate raw, primitive, often specifically female sexual energies within the cold, shiny gloss of the machine. ${ }^{6}$ I would suggest, however, that despite the thematic terrain shared by the two films, the analogy between L'Inhumaine and Metropolis is somewhat misleading, and the notion of the modern-yet-primitive, beguiling-yet-disturbing 'machine-vamp' as a convenient figure encapsulating the modernist response to technology is off the mark when it comes to L'Herbier's film. L'Herbier's cold machine-woman Claire, at least in so far as she is represented in her 'inhuman' incarnation at the beginning of the film, is very much distinct from the erotically gyrating robot Maria. Moreover, Braidotti's suggestion that Claire represents a 'superhuman', super-charged, empowered (and hence threatening) vision of woman - a vision which perhaps anticipates Haraway's formulation of the posthuman as a technologically-mediated liberation - is, I wish to argue, not quite right. ${ }^{7}$ To be sure, a Haraway-inspired conjunction of queer and posthuman approaches is highly relevant to the film and will help us to understand its complexities, and the ways in which Claire might function as a transgressive figure who undoes fixed binaries (male/female, hetero/homo, human/machine, and so on). And yet the gender politics that emerges through the film's dual concern with technology and femininity is ultimately rather more conservative, reflecting the highly fraught discourses around gender that circulated in interwar France, in the context of an overwhelming cultural and social retour à l'ordre. 
L'Inhumaine opens at the Art Deco mansion of the celebrated diva Claire Lescot, played by the opera singer Georgette Leblanc. Claire welcomes a range of male suitors - a Russian revolutionary, an American impresario, a Maharajah - to her lavish banquet hall, complete with duck moat. Each of them attempts to woo her, but she rebuffs them, announcing her imminent departure on a world tour - unless, she says, 'something' should keep her in Paris. Her final suitor, the young engineer Einar Norsen, arrives and similarly sets about wooing Claire; she callously rejects him. From the beginning of the film, then, there is an emphasis on Claire's 'inhumanity', that is to say her resistance to male desire, and especially her insensibility to the lovelorn Einar. In the opening credits, where the film's title is seen against an animated background of moving machine parts, this refusal of heterosexual love is equated to a denial of the flesh: woman becomes cold, unfeeling machine.

Einar responds to Claire's rejection by apparently driving his car into a ravine. She mourns his death but insists on satisfying her public by going ahead with a concert the next evening. Her 'inhumanity' - both her rejection of the young suitor and her apparent lack of feeling about his death - causes a near-riot in the concert hall, but she eventually wins the crowd over. She then goes to identify Einar's body, and at the peak of her emotion it is revealed that the body is a stand-in and that Einar did not die after all: it was all a trick to get her to reveal her true 'humanity', and to bring her round to his love. Claire then falls for Einar - or rather, for his mastery of technology, and for his inventions which will allow her to broadcast her voice across the world, and to see her audience via a television screen. At the end of the film, Claire is poisoned by a snake, planted in a bouquet by the insanely jealous Maharajah. Einar saves her, using a mysterious machine which reanimates her - and, even more mysteriously, somehow makes her 'human' again, recuperates her for 'humanity' (and, crucially, makes her receptive to his love). The end of the film, then, sees the emergence of a figure of woman who is no longer 'inhuman' but arguably posthuman. Claire is not brought back to life as a cyborg - that is, her body is not supplemented by any electro-mechanical or machine-produced prosthesis - but she is nevertheless posthuman in the sense that her whole recreated being is technologically mediated, and thus challenges distinctions between life and non-life, organic and inorganic, natural and artificial. She is not just reanimated but also reconfigured, in this final scene, by Einar's mysterious machine.

Little has been said in the existing scholarship about the machine that appears at the end of the film, and critical responses to L'Inhumaine have tended to focus instead on the scenes in which Claire uses technology for herself. Richard Brender and Felicia Miller Frank, for instance, have highlighted the utopianism of L'Herbier's vision of technologies of communication which are seen to unite humanity, creating a sense of a progressive and inclusive global community. ${ }^{8}$ As Miller Frank notes, however, the 'dream of panoptic vision' contained in these scenes carries what she terms an 'unexamined ideological freight'. Claire 
uses radio technology to broadcast her voice, singing to all corners of empire, while at the same time enjoying the spectacle of spectators - Europeans in their homes, places of work and in transit, but also turbaned Arabs and an African woman - listening to her. These spectators are united in their appreciation of Claire's voice, as 'the very voice of French culture'. ${ }^{9}$ In this respect, the film certainly reflects the universalist assumptions of the French colonialist project as it continued to be pursued in the 1920s.

Noël Burch has gone rather further than this in criticizing the film's ideological underpinnings, suggesting that L'Inhumaine stages the dangers of cultural cosmopolitanism (which during the First World War and after were a topic of serious and heated debate, with figures such as the notorious reactionary Camille Mauclair complaining of the pollution of traditional French culture by foreign interlopers or 'métèques'). ${ }^{10}$ This cosmopolitanism is represented by Claire's various suitors - an American Jew, a Russian communist, an oriental 'barbare' - whose offers of taking Claire to their countries of origin are ultimately rendered useless by Einar (whose surname, Norsen, highlights his Nordic, Aryan origins) and his audio-visual inventions which allow Claire to stay in France and yet be everywhere at once. According to Burch, 'C'est ainsi que la xénophobie raciste signifiée par les gueules sinistres des soupirants métèques trouve son complément: un repli hexagonal adossé à la science aryenne du beau Suédois' (Thus the racist xenophobia signalled by the gruesome faces of Claire's foreign suitors is completed by a turn back towards France [the 'hexagon'], backed up by the Aryan science of the attractive Swede). ${ }^{11}$ One might add that this metaphorical turn back (or 'repli') towards the hexagon of metropolitan France and a 'pure' French culture brought about by technologies of communication may be figured within these scenes by the hexagonal design that features prominently in multiple locations in Einar's laboratory, notably on the wall above the microphone into which Claire sings (Figure 1). < place figure 1 near here>

While Burch's view that the film ultimately anticipates the ideology of National Socialism might raise the question of whether this was a conscious agenda for L'Herbier (or whether, to go back to Miller Frank's term, this was more a matter of 'unexamined ideological freight'), it is certainly true that within L'Inhumaine apparently progressive discourses - of technology uniting humanity, for instance - sit alongside and work to conceal a more reactionary set of ideas. This also applies to the articulation of gender in the scenes where Claire uses Einar's inventions. Here Claire is ostensibly empowered by technology, since the radio and televisual equipment allows her to fulfil her desires (her desire, in particular, to reach a global audience). As the voice of French cultural imperialism, she is placed in a position of power; she sees her listeners as she sings to them, but the technology constrains them to passive reception: they do not have the opportunity to speak back. And yet it is important to note that Claire uses this technology under Einar's careful guidance, and that 
this is part of his plan to prevent Claire from leaving France, so that his own desire for her can ultimately be fulfilled. Moreover, as a user of technology rather than an inventor or creator, Claire occupies an ambivalent, intermediate position which echoes her status as a singer not-quite-artist, but rather interprète, in whom the work of art does not originate but who rather provides her body as medium of expression for the composer's creative energies. In this sense Claire herself comes to embody the qualities of the radio technology she uses, both standing as mediums or conduits for male desires and creative impulses. The way in which technology submits Claire to a certain paternal logic within the film is arguably highlighted by early publicity materials for L'Inhumaine in which Georgette Leblanc was photographed addressing a radio audience, under the apparent guidance of her co-star Jaque Catelain, and with L'Herbier himself watching close behind her: the singer-actress may be allowed to speak here, but she does so without real autonomy and as the instrument of male authority (Figure 2). ${ }^{12}<$ place figure 2 here $>$

This sense of Claire's own closeness to Einar's technological inventions of course looks forward to the posthuman Claire who emerges at the end of the film as Einar's (re)creation, and we will examine this more fully in due course. In the meantime, I wish to investigate in more detail the significance of the 'inhuman' woman represented towards the beginning of the film, and to consider the ways in which L'Herbier comes to question this notion and the assumptions about normative femininity upon which it rests. As we have already seen, the 'inhuman' Claire is associated from the outset with machines: she is an inhuman machine-woman because she is cold, cruel, selfish, concerned only with her career, and uninterested in romantic (heterosexual) love. She is also associated with the new Art Deco aesthetic - as a consumer, although not as an artist herself. The artificiality and coldness of this aesthetic is brought out by Alberto Cavalcanti's monochrome banqueting hall, and by the stark lighting on Robert Mallet-Stevens's exteriors which emphasizes their angularity and estrangement from organic forms. Estrangement from nature is further brought out through Claude Autant-Lara's highly caricatured, self-consciously artificial designs for Claire's jardin d'hiver, which provides the setting for her cruel rejection of Einar and which thus points up her distance from 'natural' heterosexual desires. Equally, one must not overlook the significations generated by the film's star, Georgette Leblanc, who as the former partner of the Symbolist playwright Maurice Maeterlinck was closely associated with the esoteric and unattainable ice maidens of Symbolist theatre (an association made evident by the original title of the film, La Femme de glace). ${ }^{13}$

Within this conjunction of Art Deco aesthetics inflected by echoes of Symbolism, Claire represents a cold, sterile, decadent modernity. ${ }^{14}$ The association between Art Deco and cultural decadence was a common trope in the 1920 s, not just in the critical reception of Art Deco design, ${ }^{15}$ but also in broader cultural representations such as Victor Margueritte's 1922 
bestseller La Garçonne, in which the moral downfall of the heroine Monique is seen to be closely bound up with her dalliance with Art Deco and the corrupt elites who consume it. ${ }^{16}$ L'Herbier's Claire is in many ways another instantiation of the figure of the garçonne broadly equivalent to the flapper - as popularized by Margueritte and others: single, financially independent, career-focused, fashionable, and (ostensibly) sexually liberated. The garçonne obsessed the post-war French imagination precisely because she posed a threat to the dual imperatives of marriage and motherhood, imperatives which came to be reinforced as France faced an apparent demographic crisis in the wake of the war. Pronatalism was so dominant on both sides of the political spectrum that even feminists accepted its premises, and treated La Garçonne with some suspicion because the suggestion that extra-marital, nonreproductive sex might be emancipatory ran counter to the perceived national interest. ${ }^{17}$ Of course, the war had brought about a number of shifts in gender roles: women had moved in increasing numbers away from the domestic sphere and into the workplace; men in the trenches were under pressure to perform a certain brand of steely masculinity while the 'hysterical' (and therefore feminine) symptoms of shell shock brought that very masculinity into question. ${ }^{18}$ This led to a generalized sense of a crisis of gender roles, which, as Mary Louise Roberts has shown, was thought to be symptomatic of a broader crisis of French civilization. ${ }^{19}$ The predominant response to this crisis was to take refuge in a retour à l'ordre and a reassertion of traditional gender identities. This is the fraught cultural context in which L'Inhumaine was produced and within which both L'Herbier's and Margueritte's garçonnes stand not simply as innocent representatives of the carefree années folles, but as highly controversial figures whose refusal of marriage and motherhood was understood to threaten the very foundations of French society.

And yet Claire is not threatening in exactly the same way as Margueritte's garçonne. She does not have the distinctive short 'flapper' haircut, or dress in the new androgynous fashions; rather she adopts a softer, albeit very flamboyant, feminine style, her costumes (designed by Paul Poiret) often trimmed with feathers and delicate furs. More importantly, Claire does not appear to be sexually liberated or promiscuous in the way that Monique is: the latter has numerous affairs with both men and women, whereas Claire, to all intents and purposes, appears to be utterly uninterested in sex, at least in the first part of the film. There is some critical debate around this point, however. Maureen Shanahan, insisting on the 'intertextuality between [Georgette Leblanc's] life and Claire's', and pointing out that Leblanc had herself been involved in a number of extramarital relationships with both sexes (including, at the time of filming, a relationship with Margaret Anderson, editor of The Little Review), ${ }^{20}$ suggests that we can take as read "Claire's implied sexual history of free love'. ${ }^{21}$ Michael Cowan, meanwhile, claims that Claire has a clear "penchant for "primitive" sexuality', using the following scene as evidence: 
Throughout the early part of the film, Claire can be seen giving bizarre soirées, in which black performers dressed in tribal attire entertain her with rhythmical dances, filmed in chaotic accelerated montage sequences. What Claire's suitors all share is the desire to bring her sexuality under control and tame the 'inhuman' woman with her exotic rhythms. ${ }^{22}$

And yet if we examine the scene in question, it is apparent that Claire remains rather aloof from the unbridled, 'primitive' sexuality represented not only by the black performers but also by the accompanying jazz band that plays for her guests. ${ }^{23}$ In the interwar period, jazz and associated dances such as the tango were commonly associated with sex and sexual desire; indeed, as Jeremy Lane remarks, in Margueritte's La Garçonne and Marcel Prévost's Les Don Juanes, the other best-seller of 1922, 'dancing to jazz in a Parisian nightclub proves the catalyst to their respective protagonists' descent into a life of immorality and sexual license. ${ }^{24}$ In L'Inhumaine, the association between jazz and sex is encapsulated in the exposed body of the black fire-eater who performs his dangerous and yet strangely fascinating act as the band plays in Claire's banquet hall, with shots of their increasingly frenetic performance juxtaposed with images of the fire-eater running flames over his skin, and a close-up of his mouth as it closes around the torch. Certainly, there is much to be said about the links between jazz and colonial ideology here, particularly as the fire-eating performance gives way to three black men dressed as soldiers with spears and shields, staging a mock battle for the entertainment of Claire's guests. ${ }^{25}$ The display of the eroticized black body is certainly not an innocent spectacle; it contains echoes of the human zoos which continued to entertain Parisian crowds well into the $1930 \mathrm{~s} .{ }^{26}$ For the purposes of the present analysis, however, the key question is how this conjunction of jazz and black flesh might bear on the construction of the 'inhuman woman'. Given the camera's close attention to the fireeater's exoticized and eroticized body, one might assume that he is an object of Claire's fascination, and that, metaphorically, she is also 'playing with fire' in terms of her own sexual desires and behaviour. In fact, the fire-eater's performance occurs in counterpoint to the episode in which Einar is rejected by Claire, with the latter taking place in the jardin d'hiver, a setting not only spatially removed from the banquet hall and the jazz performance (its separateness emphasized by the use of different coloured tints for the two spaces), but one which, as I have mentioned, seems to represent a cultivated, ostentatious artificiality, suggesting that Claire herself is estranged from nature, from the body, and from 'natural' desires. While Einar appears perturbed by the spectacle of the black performer - perhaps because it points up his own androgyny, his timid masculinity, his failure to win the object of his desires - Claire herself appears to view it dispassionately, smiling approvingly at her hired performers but showing little emotion (and, certainly, not dancing or directly participating in any 'exotic rhythms' - unlike Lang's Maria). 
What this episode seems to suggest, then, is not that Claire's wild desires need to be tamed but rather that desire must be awakened in her: she remains a cruel, inaccessible Symbolist 'femme de glace', set apart from the 'techno-primitive' influence of jazz. Jazz and sex are both present as temptations to which Claire does not succumb (and one feels that perhaps it would be better if she did). In this respect she may actually be more of a dangerous proposition than Margueritte's garçonne. Although sexually promiscuous, Margueritte's fallen woman is at least morally redeemable, since her out-of-control desires can potentially be rechannelled and brought back under control - and in fact Monique does come round, later in Margueritte's trilogy of novels, to both marriage and motherhood. ${ }^{27}$ Claire, as played by Leblanc, is manifestly too old for motherhood (Leblanc was in her fifties when she took the role) but, even more crucially, is unreceptive to male desire. She needs not just a moral reeducation but a complete transformation, and eventually will be 'remade' by Einar's technology into a desiring, and in turn receptive, heterosexual partner. That resistance to male desire is the defining characteristic of the 'inhuman' woman is suggested by a number of further intertextual references embedded within Claire's name: while her first name contains within it the spirit of the electric age and anticipates the 'éclair' or flash of electricity that will bring her back to life at the end of the film, her surname, Lescot, is homonymically resonant with the eponymous recalcritrant prostitute of L'Abbé Prévost's Manon Lescaut (1734), and also contains a nod to the virtual model Catherine Lescaut in Balzac's novella Le Chefd'œuvre inconnu $(1831){ }^{28}$ The first of these characters exploits and rebuffs male desire, while the second stands as an imagined vessel for that desire, a figure so idealized that Balzac's fictional painter Frenhofer cannot realize her portrait, cannot tie her down or possess her via her painted image. Claire's 'inhumanity' similarly derives from her unattainability, and her unwillingness to service the fantasies of her multiple male admirers.

While both jazz and the Art Deco aesthetic might carry an association with moral decadence, L'Herbier does not seem explicitly to criticize these cultural phenomena: indeed, L'Inhumaine was conceived partly to showcase the 'modern style', acting as an 'avantpropos' to the 1925 Exposition des Arts Décoratifs. ${ }^{29}$ The film does, however, offer up a series of condemnations of Claire herself, as she rejects Einar, apparently causing his suicide, and insists on performing in a concert the next evening. Her audience's violent reaction may be partly explained by the fact that Claire appears to reject the proper codes of female mourning - a particularly emotive stance in the post-war context because it simultaneously evokes and denies the figure of the war widow, in the popular imagination often seen as a 'helpless object of pity'. ${ }^{30}$ Claire offends, perhaps, because she does not publicly perform her mourning in a suitably helpless or pitiable way. And yet as spectators of the film we know that she is not actually 'inhuman' in the way the public assume: we see her agonizing over her decision to perform, and later, when she sees what she thinks is Einar's dead body, she does 
weep and wail 'in a fashion proper for a postwar widow'. ${ }^{31}$ The concert-hall riot, then, is framed in such a way as to make the audience's condemnation of Claire seem unjust, and to align our sympathies with her. Moreover, there are two further instances in which critiques of Claire's 'inhuman' behaviour are rendered highly ambivalent, raising questions about the moral status of her critics, and also about the normative models of femininity (that is, assumptions about what constitutes an 'inhuman' woman, and what a 'real' or human woman is and should be) upon which their utterances rest. In the first of these, we see Claire condemned by a matronly older woman ensconced in a chintzy, crowded bourgeois interior: scandalized by a gossip-column about the 'insensible' Claire, the woman declares, 'Cette Lescot, quelle vie scandaleuse! Des femmes comme ça on devrait les enfermer!' (That Lescot, what a scandalous life she lives! Women like that should be locked up!) The woman's implied position of moral superiority is, however, undercut when she leans in to give a passionate kiss to a much younger man one might have assumed was her son.

The second example occurs in the scene immediately following, where we encounter a butcher who reads alternately as male or female, or as indeterminate. ${ }^{32}$ On close examination, the butcher appears to be a female actor dressed to look male, with ostentatiously fake eyebrows and longer hair styled to mimic a masculine cut - but of course what is critical here is not so much the 'reality' of the actor's or indeed the character's gender but rather the way in which this figure troubles our sense of stable, binary gender identities, by querying the notion of a 'real' gender underlying the performance of cross-dressing. The butcher's gender ambiguity - indeed, his/her aberrant femininity - is highlighted by a sign in the butcher's shop, which reads 'boudin' (Figure 3). <place figure 3 near here $>$ This refers literally to the sausage on display on the counter - itself an obvious phallic symbol - but 'boudin' is also a gendered slang term, approximating to something like 'fat tart'. Clearly, the notion of flesh or meat is important in this episode, as is its opposition to the inhuman meatgrinding machine seen within shot, and these elements frame the butcher's critique of Claire, displayed as an intertitle: 'C'est y pas pitié... une femme sans entrailles!' Now, 'entrailles' means guts or intestines, and this type of offal is also on sale in the butcher's shop, as pointed up by another sign. But 'entrailles' can also refer to the female reproductive organs, and within the butcher's framing, Claire is 'inhuman' not just because she rebuffs male desire (because she lacks 'normal' sexual feeling) but also, implicitly, because she has avoided motherhood, which as we have already noted was seen in the pronatalist discourses of the $1920 \mathrm{~s}$ as a cultural necessity and is present as an unspoken imperative within the film. The conjunction of flesh and machine within the butcher's shop scene also points to the way in which these pronatalist discourses encouraged women to abandon the work they had taken on in wartime (often at the helm of machines, in munitions factories and so on), and return to their 'natural', biologically-determined work of the flesh, as wives and producers of children. 
Once again, it is clear that L'Inhumaine provides an arena for a reactionary discourse on gender; yet in the two examples just cited, L'Herbier ironically undermines this discourse, highlighting its hypocrisy by placing it in the mouths of figures who are themselves hardly 'model' examples of normative femininity. The fact that the femininity (and therefore the moral status) of these women is subject to question gives rise to a pervasive sense of 'gender trouble' within the film: a sense that the women in the film, not to mention the androgynous Einar, upset stable gender identities, and indeed bring these into question in quite a radical way - a sense, ultimately, that no one is doing 'being a woman' in quite the way they are supposed to. There are two possible counterpoints to the aberrant femininities displayed via Claire, the butcher and the bourgeois woman: the first of these is the painter's model, artist and writer Kiki de Montparnasse, who appears briefly in a painter's studio during the sequence in which Claire sees her listeners via television. Here, Kiki models for a male painter, her body apparently exposed to the waist and her arms held above her in a pose reminiscent of some of Matisse's odalisques. While this pose perhaps connotes an easy sensuality seen through an orientalizing lens (and contrasting with Claire's apparent frigidity), it is difficult to see Kiki in this scene as a 'model' woman, not least because female models' exposure of their bodies meant that they were frequently associated with prostitutes. Kiki herself was of course known for her extramarital relationships with male artists, and these (as well as her boyish cropped hair) link her closely with the deviant garçonne. ${ }^{33}$ The second possible counterpoint is the peasant girl who witnesses Einar's apparent suicide and who comes to Claire's mansion to alert her to the tragedy - but the girl in question is so timid, so naive and so grubby that she hardly appears as an idealized embodiment of 'natural' or traditional femininity. Indeed, that she incarnates an outmoded and unrealistic image of woman is made clear by her archaic donkey and cart - and by the fact that the same character apparently dies later in the film while listening to Claire's radio broadcast, in a scene not without pathos but nevertheless suggestive of the triumph of the new, 'troubled' femininity, over the old.

All of this suggests that there is, at the very least, a queer potentiality to L'Inhumaine, and that the film does not so much propose as question fixed models of femininity and of female sexual desire. This queer potentiality may well have been picked up on by its original audiences, who sensed that the central coupling between Claire/Leblanc and Einar/Catelain was unintelligible as a heterosexual romance - a factor that is often blamed for the film's commercial failure. The disparity in age between the fifty-something Leblanc and the twentysix year old Catelain might have been one source of discomfort for audiences, and may have been one reason why Pierre Mac Orlan, in his novelization of L'Inhumaine, was so keen to point up Claire's youth and her status as malleable ingénue. ${ }^{34}$ But one might also point to the queer significations generated by Leblanc herself, as already mentioned, and indeed by 
Catelain, who was apparently in a relationship with L'Herbier. ${ }^{35}$ While other explanations for this failed coupling are possible (Benoît-Jeannin, for instance, suggests that American censorship rules were to blame for the fact that the film's central couple never actually embrace, as if an embrace would somehow have satisfied audiences and legitimized the central coupling), ${ }^{36}$ the fact remains that the film itself gestures towards the heroine's own queerness, her position outside fixed categories. Branded a 'femme étrange' from the first intertitle in which she is introduced, her sexuality is euphemistically suggested by the bourgeois woman's reference to her as 'une femme comme ça', and then the butcher's comment that she is 'une femme sans entrailles' - coded not specifically as lesbian but as indeterminate, non-normative, aberrant, lacking 'normal' heterosexual desire. Shanahan also convincingly argues that the film's theme of disguise and masquerade - from the masked servants at the banquet, to the disguise Einar uses to trick Claire, to the butcher(ess) already discussed, to the cross-dressing women briefly shown at Claire's concert - gives rise to a playful, subversive space in which gender and sexual identities can be explored and questioned. ${ }^{37}$ Reading the film through the lens of queer theory, one might argue both that it stages various moments in which gender identity is rendered indeterminate or unintelligible, and (through the figure of the butcher in particular) that it mobilizes the subversive potential of drag, which in Judith Butler's analysis parodies and reveals the 'imitative structure' of gender itself. ${ }^{38}$

I certainly do not wish to deny the film's queer potentiality, but I would contend that previous studies have not been sufficiently attentive to the way in which this queer space is effectively shut down towards the end of the film, where Claire is reanimated and brought round to the imperatives of humanity (and by 'humanity', I think we can read 'man'). She is remade by technology - but, like a new Galatea, she is sculpted according to the desires of her creator, Einar. In order to support this claim, I propose to look in detail now at the film's closing sequences, and at the machine used to reanimate Claire. There is certainly, as Standish Lawder remarks, an 'intense electrical and mechanical activity that pulsates from the screen during the final scene of L'Inhumaine, ${ }^{39}$ but this begs the question: what exactly is the machine seen in these final sequences? How is it supposed to function? How does L'Herbier represent it? And crucially, what are the ramifications of this representation for the film's articulation of a transformed, 'posthuman' woman?

The machine in question is in fact shown several times towards the end of the film, in the scenes taking place in Einar's laboratory, with sets designed by Fernand Léger. At first Claire sees only the control panel (Figure 4), a weird amalgam of wires and glass tubes, labelled 'danger de mort' (danger of death). <place figure 4 near here> It lights up briefly, suggesting a spontaneous life force within. Einar tells Claire only that it is a powerful and dangerous machine - but she is clearly drawn to it, and indeed she rapidly gets over Einar's 
trickery and agrees to come back to the laboratory to find out more. Her attraction to the machine is made even more apparent by a subsequent sequence in which Claire dreams about Einar and the lab, and we are told that 'Toute cette science féerique entrevue chez Einar attire Claire comme quelque chose d'aussi imprévu... aussi fort que l'amour' (all of this magical science glimpsed at Einar's attracts Claire, like something as unexpected and as powerful as love). ${ }^{40}$ The machine, it seems, may be the special 'something' that will keep Claire from straying overseas.

Our second glimpse of this machine occurs a little later, after Claire has experimented with Einar's radio and televisual inventions. This time Claire sees a new part of the machine, made up of a few schematic elements - a static frame at the front, combined with spinning disks - and as before, she is visibly excited by what she sees, at one point shushing Einar so that she can concentrate on the machine (Figure 5). $<$ place figure 5 near here $>$ Einar tells her that this part of the machine is connected to the console she saw previously. He goes on to explain (via two intertitles) that the machine 'produit une force capable d'effets insoupçonnés' (produces a force capable of unforeseen or surprising effects), 'peut-être de ranimer les mouvements du cœur' (perhaps reanimating the movements of the heart). No further explanation is given and it remains unclear how the machine might work in practice but crucially, a link between the machine and the human heart is established here, to be built upon in the final sequences.

The next time we see the machine is when Claire's body has been brought back to Einar's laboratory to be resuscitated. In this sequence, Einar fiddles with his complicatedlooking control panel, while his masked assistants run about the laboratory tinkering; lights flash erratically; Claire, meanwhile, lies on a platform in a completely separate chamber (the different spatial locations being emphasized again by different coloured tints). The machine is supposed to be doing something to her, but it is not quite clear what: there are no wires or electrodes attached to her, no bits of machinery in contact with her body; only two zigzagging tube lights on either side of her, suggestive of electrical impulses. Of course, this approach to the machine is typical of the simplified mechanical elements that we see in Léger's paintings of the period, and in the pseudo-machines of Picabia or Duchamp, bachelor machines that appear capable of moving and pumping but do not make sense as tools performing a function. This is the aesthetics of the machine abstracted from function; but in reducing the machine to its schematic appearances there is also an attempt to mythologize it by leaving room for it to perform 'magic': this is, after all, supposed to be an 'histoire féerique', a fairytale or marvellous story, as we are told in the opening credits. Throughout the film and indeed in Pierre Mac Orlan's subsequent novelization there is an emphasis on the ineffable poetry of the machine, its mystery, its 'féerique' quality, a notion which is of course at odds with technicalities and involved demonstrations of how things actually work. ${ }^{41}$ But 
this mystery surrounding the machine also makes room for other readings, which we will come to shortly.

The action gathers pace as the first attempt to revive Claire fails and Einar begins another attempt; we are told that the laboratory is animated 'comme dans une symphonie de travail' (as in a symphony of labour). Indeed, the machine seems by now to encompass the whole laboratory space, with Léger's swinging pendulum acting as a kind of metronome, regulating and coordinating a host of disparate elements. In this sequence, we see some very rapid cutting, similar to the famous train crash scene in Abel Gance's La Roue (1923), and similar in many ways to the editing techniques and machine imagery of Léger's own film Ballet mécanique, released the same year as L'Inhumaine. ${ }^{42}$ L'Herbier also uses plain coloured screens intercut very briefly with the filmed footage to give flashes of bright colour, echoing the flickering lighting and giving the impression of bolts of electricity. Alongside this, we see L'Herbier using superimposition to show swinging pendulums and other machine parts over the top of images of the workers moving about. This sets up a parallel between the movements of the human workers and those of the machines, coming together indeed in a kind of harmonious 'symphony' - a marriage, even, of human and machine, of which the reanimated Claire is the ultimate outcome. The pace builds to a point where it is positively climactic, and we see Einar in a frenzy while Claire, in her semi-conscious state, also appears to be enjoying herself very much indeed: as she begins to awaken, her eyes roll back and she smiles blissfully. During this sequence we flash back to the sign on the control panel, 'danger de mort', which now seems to evoke for us the possibility of 'la petite mort', jouissance, or orgasm.

What I wish to suggest, then, is that this is not just a machine that gives life: it is a love machine. It is a machine that clearly turns Claire on, in more than one sense. With this in mind, I would suggest that the end of $L$ 'Inhumaine should be read in relation to the revelatory historical work done by Rachel Maines on the technology of orgasm. Maines shows that in the late nineteenth and early twentieth centuries, electromechanical vibrators were routinely used by doctors, in France and throughout developed countries in the West, to treat a variety of female psychosexual disorders, including frigidity and hysteria (which Maines reads as itself symptomatic of sexual frustration). ${ }^{43}$ Just as many women in this period were relieved of their hysterical symptoms by doctors wielding vibrators, Claire is apparently 'cured' of her inhumanity (that is to say, her non-normative sexuality) by Einar's love machine. Rendered pliant by this treatment, she is finally ready for her big clinch, which L'Herbier merely suggests by having the lovers gaze adoringly at one another in the final shot (Figure 6). $<$ place figure 6 near here $>$ Claire is not just brought back to life, but submitted to the male space of the laboratory and delivered from her resistance to heterosexual love. Einar therefore stands here not just as lover but as doctor, guiding Claire's sexual and moral re-education. As 
is the case in the broader corpus of literary and filmic representations of machine-women, the male protagonist also stands as a Pygmalion-like figure: Einar refashions the 'inhuman' woman according to his own desires (and it is his machine that renders her flesh malleable, that removes its resistance to the sculptor-lover's touch). ${ }^{44}$

Paradoxically, then, it is the 'inhuman' love machine that recuperates Claire and makes her 'human': technology is seen here as warm and humanizing, rather than cold and unfeeling. This implies a certain utopian optimism about the power of technological innovation, and Shanahan is perhaps correct to suggest that Claire's reanimation may be a metaphor for the use of technology in the reconstruction of post-war France. ${ }^{45}$ If this is the case, however, I would suggest that L'Herbier's vision of post-war reconstruction strongly implies a return to a pre-war division of labour along gendered lines, and to stable, traditional gender identities. ${ }^{46}$ L'Inhumaine is certainly a film that persistently queries conventional notions of femininity and what it might mean to be a 'strange' or 'inhuman' woman; it certainly plays with queer significations and may be viewed, broadly speaking, as participating in queer modernism(s). However, commercial considerations may well have worked to make its message less radical, L'Herbier seeking to appeal not just to queer and avant-garde spectatorial positions, as Shanahan argues, but also, crucially, to a mainstream, broadly conservative spectatorship. ${ }^{47}$ Caught between modernist experimentation and his audience's desire for a conventional narrative resolution, L'Herbier's film - like many postwar silent films belonging to what Abel calls the 'narrative avant-garde', which often draw heavily on the conventions of nineteenth-century melodrama - ultimately provides a 'happy ending' which works to deny Claire's queerness and restore moral order. ${ }^{48}$ L'Inhumaine does not present a vision of technology that liberates woman, or even generates female pleasure for pleasure's sake; rather, the love machine is a tool to shape and subjugate female desires to respond more readily to male needs. Moreover, the posthuman Claire that emerges at the end of the film is not a 'superhuman' figure or a 'machine-vamp' who might stand to threaten binary notions of gender, or patriarchal order. She is, instead, a more docile and reassuring figure, close to Margueritte's chastened and reformed garçonne, who repents for her deviant sexuality and is ultimately brought back within the patriarchal fold. 
${ }^{1}$ I have worked from the restored version on DVD (Lobster Films, 2015).

${ }^{2}$ On the early reception of L'Inhumaine, see Richard Abel, French Cinema: The First Wave, 1915-1929 (Princeton: Princeton University Press, 1984), p. 383. L'Herbier himself noted that the film only began to get a positive reception after 1968, and especially around the fiftieth anniversary of the 1925 Exposition des arts décoratifs when the film's Art Deco credentials were reassessed: see Marcel L'Herbier, La Tête qui tourne (Paris: Belfond, 1979), pp. 104-6. Abel's work, along with that of Noël Burch, has been instrumental in what Burch sees as the 'rehabilitation' of both L'Herbier and L'Inhumaine since the 1970s: see Noël Burch, In and Out of Synch: The Awakening of a Cine-Dreamer, trans. by Ben Brewster (Aldershot: Scolar Press, 1991), p. 32.

${ }^{3}$ See Marjorie Perloff, The Futurist Moment: Avant-Garde, Avant-Guerre, and the Language of Rupture, 2nd edn (Chicago University Press, 2003). The film's title for its 1927 Italian release was 'Futurismo'; on the film's affiliations with Italian Futurism, see Antonio Costa, 'Les (Més)Aventures de Monsieur L'Herbier au pays des futuristes', in Marcel L'Herbier: L'Art du Cinéma, ed. by Laurent Véray (Paris: Association Française de Recherche sur l'Histoire du Cinéma, 2007), pp. 91-100.

${ }^{4}$ Rosi Braidotti, The Posthuman (Cambridge: Polity Press, 2013), p. 105-6. Braidotti's reading of these films, and her use of the term 'machine-vamp', is indebted to Andreas Huyssen, 'The Vamp and the Machine: Fritz Lang's Metropolis', in After the Great Divide: Modernism, Mass Culture, Postmodernism (Bloomington and Indianapolis: Indiana University Press, 1986), pp. 65-81.

5 Walter Benjamin, 'The Work of Art in the Age of Mechanical Reproduction', in Illuminations, trans. by Harry Zohn, ed. by Hannah Arendt (London: Pimlico, 1999), pp. 21144.

${ }^{6}$ Hal Foster, Prosthetic Gods (Boston: MIT Press, 2004), p. 341, n. 3. The term 'technoprimitive' is taken up in relation to jazz by Jeremy F. Lane, Jazz and Machine-Age Imperialism: Music, 'Race', and Intellectuals in France, 1918-1945 (Ann Arbor: University of Michigan Press, 2013), p. 6, pp. 35-64, etc, and in connection with modernist representations of female sexuality by David Trotter, Literature in the First Media Age: Britain Between the Wars (Cambridge, MA: Harvard University Press, 2013), pp. 86-119.

${ }^{7}$ Donna Haraway, 'A Cyborg Manifesto: Science, Technology, and Socialist-Feminism in the Late Twentieth Century', in Simians, Cyborgs and Women: The Reinvention of Nature (New York: Routledge, 1991), pp. 149-81.

${ }^{8}$ Richard Brender, 'Functions of Film: Léger's Cinema on Paper and on Cellulose, 1913-25', Cinema Journal, 24.1 (Autumn 1984), 41-64 (p. 47); Felicia Miller Frank, 'L'Inhumaine, La Fin du monde: Modernist Utopias and Film-Making Angels', MLN, 111.5 (December 1996), 
938-53. As both Brender and Miller Frank argue, utopian elements can be seen in a number of other interwar representations of cinema technology; in addition to the texts they analyse, one might note especially C.-F. Ramuz's 1924 novel L'Amour du monde (Lausanne: Plaisir de lire, 1980), in which the cinema gives rise to a panoptic sense of the global, and texts by Blaise Cendrars such as L'ABC du cinéma and Le Principe de l'utilité (in Aujourd'hui, in Tout autour d'aujourd'hui, ed. by Claude Leroy, 15 vols (Paris: Denoël, 2001-06), XI, 29-33 and 35-46), both of which envision cinema as a universal language.

${ }^{9}$ Miller Frank, 'L'Inhumaine, La Fin du monde', pp. 939-41.

${ }^{10}$ Camille Mauclair, Les Métèques contre l'art français. La Farce de l'art vivant, II (Paris: Nouvelle revue critique, 1930).

${ }^{11}$ Noël Burch, ‘Ambivalences d'un auteur "bisexuel”. Quatre films de Marcel L'Herbier', in Marcel L'Herbier: L'Art du Cinéma, ed. by Laurent Véray (Paris: Association Française de Recherche sur l'Histoire du Cinéma, 2007), pp. 201-16 (p. 207).

${ }^{12}$ I would also tentatively suggest that this photograph parallels the way in which, as Sam Halliday has remarked (Sonic Modernity: Representing Sound in Literature, Culture and the Arts (Edinburgh: Edinburgh University Press, 2013), pp. 1-3), L'Inhumaine tends to transform listening into a visual experience, thus foregrounding Leblanc/Claire's status as object of the male gaze rather than creative subject.

${ }^{13}$ L'Herbier, La Tête qui tourne, pp. 100-03.

${ }^{14}$ See Burch, “Ambivalences d'un auteur "bisexuel”, p. 207.

${ }^{15}$ For instance, the critical response to the Art Deco aesthetic on display at the 1925 Exposition des arts décoratifs emphasized its elitism and unhealthy indulgence in luxury. See Kenneth E. Silver, Esprit de Corps: The Art of the Parisian Avant-Garde and the First World War, 1914-1925 (Princeton: Princeton University Press, 1989), pp. 365-66. Romy Golan also notes that 'the preciosity of art deco [was] unfavourably associated with money and privilege': Modernity and Nostalgia: Art and Politics in France Between the Wars (New Haven and London: Yale University Press, 1995), p. 93.

${ }^{16}$ Victor Margueritte, La Garçonne (1922; Paris: Le Livre de Poche, 1948). On Margueritte's representation of Art Deco, see Élodie Lacroix di Méo, 'Art, politique et émancipation des femmes dans la trilogie La Femme en chemin (1922-4) de Victor Margueritte', in Art in French Fiction since 1900, ed. by Katherine Shingler (= Nottingham French Studies, 51.3 (2012)), pp. 261-71.

${ }^{17}$ Anne-Marie Sohn, 'La Garçonne face à l'opinion publique: type littéraire ou type social des années 20?', Le Mouvement social, 80 (July-September 1972), 3-27.

${ }^{18}$ On this crisis of masculinity, see Elaine Showalter, The Female Malady: Women, Madness and English Culture, 1830-1980 (London: Virago, 1987), pp. 167-74. 
${ }^{19}$ Mary Louise Roberts, Civilization without Sexes: Reconstructing Gender in Postwar France, 1917-1927 (Chicago and London: University of Chicago Press, 1994), esp. pp. 1-16. ${ }^{20}$ See Maxime Benoît-Jeannin, Georgette Leblanc (Brussels: Le Cri, 1998), pp. 386-89 and 391-96, and Mathilda M. Hills's introduction to Margaret Anderson, Forbidden Fires (Tallahassee, FL: Naiad Press, 1996), pp. 6-10; Anderson's use of 'Claire Lescaut' as a pseudonym for a fictionalized Leblanc in this text seems to confirm the interchangeability of actress and character.

${ }^{21}$ Maureen G. Shanahan, 'Indeterminate and Inhuman: Georgette Leblanc in L'Inhumaine (1924)', Cinema Journal, 43.4 (Summer 2004), 53-75 (pp. 59 and 61).

${ }^{22}$ Michael Cowan, "The Heart Machine: "Rhythm" and Body in Weimar Film and Fritz Lang's Metropolis', Modernism/Modernity, 14.2 (April 2007), 225-48 (p. 240).

${ }^{23}$ The original music for the film, by Darius Milhaud, has unfortunately been lost: see Abel, French Cinema: The First Wave, p. 388.

${ }^{24}$ Lane, Jazz and Machine-Age Imperialism, p. 54.

${ }^{25}$ In his reading of this scene, Matthew F. Jordan suggests that there are links between jazz and the film's critique of cultural cosmopolitanism: see Le Jazz: Jazz and French Cultural Identity (Urbana, Chicago and Springfield: University of Illinois Press, 2010), p. 83.

${ }^{26}$ On the practice of displaying the black body as a curiosity, see Elizabeth Ezra, 'Colonialism Exposed', in The Colonial Unconscious: Race and Culture in Interwar France (Ithaca: Cornell University Press, 2000), pp. 21-46.

${ }^{27}$ See Victor Margueritte, Le Compagnon (Paris: E. Flammarion, 1923); on this resolution, see Roberts, Civilization without Sexes, p. 57.

${ }^{28}$ Claire's first name also suggests a link with two further texts that imagine artificial women: with the Klara of Hoffman's Der Sandman (1816), and with Alicia Clary, the model for the 'andréide' Hadaly in Villiers de l'Isle-Adam's L'Ève future (1886).

${ }^{29}$ L'Herbier, La Tête qui tourne, p. 104.

${ }^{30}$ Roberts, Civilization without Sexes, p. 292, n. 51.

${ }^{31}$ Shanahan, 'Indeterminate and Inhuman', p. 56.

${ }^{32}$ Shanahan, 'Indeterminate and Inhuman', p. 56 and 65 misreads this figure as a seamstress (perhaps because of the machinery in the butcher's shop which resembles the wheel of a sewing machine).

${ }^{33}$ Kiki was a celebrity in 1920s Montparnasse and a familiar figure to the artistic set with which L'Herbier associated, but it is unclear whether by 1924 a broader audience would have recognized her in the film; her status as a figure in popular culture was really sealed with the 1929 publication of her Souvenirs. On Kiki, her writing, and the way she walked a thin line between prostitution and free sexual activity, see Richard Scholes, 'Model Artists in Paris: 
Hastings, Hamnett, and Kiki', in Paradoxy of Modernism (New Haven: Yale University Press, 2006), pp. 221-56.

${ }^{34}$ Pierre Mac Orlan, L'Inhumaine (Paris: Albin Michel, 1925), p. 4. Claude Autant-Lara, La Rage dans le cœur: chronique cinématographique du 20e siècle (Paris: Veyrier, 1984), pp. 277-91 blames Leblanc's age (and character) for the film's failure, in the most damning terms. Marie Martin, “Féerie réaliste”, onirisme et pratiques maniéristes dans l'œuvre de Marcel L'Herbier, de Rose-France (1918) à La Nuit fantastique (1942)', in Marcel L'Herbier: L'Art du Cinéma, ed. by Laurent Véray (Paris: Association Française de Recherche sur l'Histoire du Cinéma, 2007), pp. 169-90 (pp. 187-88) suggests that the 'oedipal' relationship between the central couple is a source of some discomfort. One might add that this oedipal relationship is parodied and made more explicit through the bourgeois woman and her son-lover.

${ }^{35}$ Burch, ‘Ambivalences d'un auteur "bisexuel”, p. 204.

${ }^{36}$ Benoit-Jeannin, Georgette Leblanc, p. 410.

${ }^{37}$ Shanahan, 'Indeterminate and Inhuman', esp. p. 63. Burch also proposes a queer reading of the film, noting that there is a 'discours pervers qui sous-tend un film si conventionellement conservateur en surface' (a queer discourse subtending a film that appears on the surface to be conventionally conservative). 'Ambivalences d'un auteur "bisexuel”, p. 209.

${ }^{38}$ Judith Butler, Gender Trouble: Feminism and the Subversion of Identity, 2nd edn (London: Routledge, 1999), esp. pp. 186-87, on drag.

${ }^{39}$ Standish D. Lawder, The Cubist Cinema (New York: New York University Press, 1975), p. 110.

${ }^{40}$ Pierre Mac Orlan's novelization also describes the machine as exerting a kind of sexual charm over Claire, and emphasizes that Einar has conceived it 'à un dessein d'amour' (for the purposes of love): see Mac Orlan, L'Inhumaine, pp. 51 and 54.

${ }^{41}$ See Mac Orlan, L'Inhumaine, p. 45: 'Un lyrisme neuf, singulier et puissant se dégageait de cette féerie scientifique. Des noms de poètes vinrent aux lèvres de Claire Lescot.' (A new lyricism, unique and powerful, emanated from this scientific mystery. Names of poets entered Claire Lescot's mind.) The American title of the film was The New Enchantment (BenoitJeannin, Georgette Leblanc, p. 409).

${ }^{42}$ On the montage techniques used in these films (as well as in René Clair's Entr'acte, 1924, produced slightly later and apparently in response to L'Inhumaine), see Chris Townsend, 'The Last Hope of Intuition: Francis Picabia, Erik Satie and René Clair's Intermedial Project Relâche', in The French Avant-Garde, ed. by Stephen Forcer and Emma Wagstaff (= Nottingham French Studies, 50.3 (Autumn 2011)), pp. 43-66 (pp. 56-58). There is of course much to be said about the thematic terrain shared by L'Inhumaine and Ballet mécanique; for 
some comments on gender and technology in the latter, see James Donald, 'Jazz Modernism and Film Art: Dudley Murphy and Ballet mécanique', Modernism/modernity, 16.1 (January 2009), 25-49 (pp. 38 and 43).

${ }^{43}$ Rachel P. Maines, The Technology of Orgasm: 'Hysteria', the Vibrator, and Women's Sexual Satisfaction (Baltimore and London: Johns Hopkins University Press, 1999).

44 For a broad analysis of the Pygmalion myth's relevance to the wider corpus of representations of machine-women, see Julie Wosk, My Fair Ladies: Female Robots, Androids, and Other Artificial Eves (New Brunswick, NJ: Rutgers University Press, 2015); on the particular pertinence of the Pygmalion myth in cinema, see Michelle E. Bloom, 'Pygmalionesque Delusions and Illusions of Movement: Animation from Hoffmann to Truffaut', Comparative Literature, 52.4 (Autumn 2000), 291-320.

${ }^{45}$ Shanahan, 'Indeterminate and Inhuman', p. 57. Abel, French Cinema: The First Wave, p. 393, suggests an alternative reading, according to which the final sequences are a metaphor for cinema itself, as a machine that (re)animates.

${ }^{46}$ Even if they do not read Einar's machine in terms of the technology of orgasm, a number of other critics have also pointed out the conservative gender politics emerging at the end of L'Herbier's film: see for instance Abel, French Cinema: The First Wave, p. 394; Townsend, 'The Last Hope of Intuition', p. 58; and Shanahan, 'Indeterminate and Inhuman', p. 57.

${ }^{47}$ Shanahan, 'Indeterminate and Inhuman', p. 66. It is clear from L'Herbier's own account (La Tête qui tourne, p. 100) and Autant-Lara's (La Rage dans le cour, pp. 277-78) that L'Herbier's Cinégraphic production company badly needed the film to be a commercial success.

${ }^{48}$ On the term 'narrative avant-garde' see Abel, French Cinema: The First Wave, p. 279; the category includes filmmakers such as Abel Gance and Jean Epstein alongside L'Herbier. Similar narrative resolutions, and restorations of moral order, occur at the end of other films by L'Herbier, such as his Feu Mathias Pascal (1926) and L'Argent (1928), both based on literary texts (Pirandello and Zola). 